\title{
Research and Exploration of Internet Finance Helping Financing Problem of Small and Micro Enterprises in Shandong
}

\author{
Xuefei Hong \\ Shandong Institute of Commerce and Technology, Shandong, Jinan, 250103
}

Keywords: small and micro enterprise; Internet finance; risk control; Internet platform

\begin{abstract}
The rapid development of the small and micro enterprise type has become an important force for stimulating China's economic growth and the main carrier for absorbing social employment. Small and micro enterprises play an irreplaceable function and role. However, due to the relatively short development and establishment of small and micro enterprises in China, these small and micro enterprises still face more problems and difficulties, especially in financing. Small and micro enterprises have relatively low credibility and a small number of fixed assets, which makes these enterprises have greater difficulties in financing. Financing difficulties have undoubtedly become an important reason hindering the development of small and micro enterprises. According to the reasons for the financing difficulties of small and micro enterprises in China, effective measures can be taken to promote the its further development in China and play an important role in promoting the development of the national economy.
\end{abstract}

\section{Introduction}

According to the statistics of Shandong Industrial and Commercial Bureau, by the end of 2017, there were 2 million small and micro enterprises in Shandong Province, accounting for 89\% of the total number of enterprises. The registered capital was 9.9 trillion yuan, ranking third in the country after Guangdong and Jiangsu. The province's individual and private enterprises have accumulated a total of 26.58 million employed people. In 2017, the province's small and micro enterprises achieved operating income of 3.05 trillion. Therefore, it is not difficult to see that small and micro enterprises in Shandong Province have become the backbone of Shandong's economic development. However, when small and micro enterprises are developing rapidly, their demand for funds is even more urgent. However, due to the small scale of business, lack of collateral, asymmetric corporate information, insufficient credit guarantees, etc., financial institutions refused loans, or financing problems such as high loan interest all restrict the development of small and micro enterprises. Therefore, it helps small and micro enterprises to obtain more financial assistance and make them develop healthily and rapidly, thus ensuring the rapid and healthy development of Shandong's economy and society.

\section{Literature Review}

In 2013, as the first year of Internet finance, with the support of big data and cloud technology, it created a new model of Internet + finance combining Internet and financial industry. The rapid development of Internet finance has solved some unsolvable problems in the traditional financial industry and provided a new way for the financing problems of small and micro enterprises. Xie Ping and Zou Chuanwei (2012) proposed the new model of "Internet finance" for the first time. They pointed out that Internet finance can reduce the cost of information processing and improve the efficiency of financial resource allocation by relying on information technology such as big data. Huang Zijian (2015) proposed to build an Internet finance model combining microinsurance and microfinance to solve the problem of insufficient credit guarantee for small and micro enterprises. Liu Wei and Zhu Ruibo (2014) believe that Internet finance can solve the problem of financing difficulties for small and micro enterprises by establishing a detailed credit information system. Yue Yuxi (2017) proposed that Internet finance's achievements in the information asymmetry and 
excessive credit costs of small and micro enterprises in the financing process are obvious to all. Wang Xin (2015) believes that the development of Internet finance has made up for the appropriate money supply gap, reduced the credit ratio, promoted the rational allocation of financial resources, and provided a new perspective for solving the financing dilemma of small and micro enterprises. Xie Ping (2012) explained the main core content of the Internet financial model: resource allocation, payment methods and information processing. Internet finance has the special transparency of e-commerce, which solves the problem of information asymmetry between bank enterprises under the traditional lending model. Zhang Wei (2016) proposed that because the Internet financial system is not subject to strict legal control, there will be more risks in the process of providing financing services for small and micro enterprises, resulting in corporate losses. The government should improve the regulatory policies of the Internet financial system and introduce corresponding laws and regulations.

\section{Internet Finance Contributes to the Financing of Small and Micro Enterprises}

Reduce data and transaction costs through big data. By re-integrating the information results and analyzing and mining the massive data accumulated by the e-commerce platform and the social network, Big Data can obtain more authentic data than the actual enterprise release, reduce costs through the network, and collect the amount of data. In-depth analysis enables credit management for customers to be achieved through analysis of big data.

The financing method of internet finance is more targeted. Internet finance provides a new financing channel for small and micro enterprise financing, so that it can be arbitrarily selected under the background of powerful information of the Internet to realize the improvement, innovation and expansion of the financing mode of small and micro enterprises. Small and micro enterprises can quickly find specialized information resource services in technology, information and consulting through the huge platform of the Internet. In view of the fast, efficient, low-cost and simple features of Internet finance, the operating threshold is greatly reduced, which helps to realize the financing of small and micro enterprises. Internet finance enables small businesses to make their own choices and find the financing method that suits them best.

Internet finance successfully introduced mass power. Small and micro enterprises can use the online financial platform to guide the public to integrate their idle funds through preferential conditions to achieve mutual benefit. Small and micro enterprises can publish financing information on the financial platform, or carry out pre-sale work. Under this model, the general public can also contribute and benefit from the development of financial leasing. For financing companies, it is only necessary to put those projects that have been reviewed by the risk control system and considered to be profitable on the platform. Consumers can choose according to the combination of financing demand and profit rate, which is more operative and investment. People also have more choices.

\section{Problems in the Implementation of Microfinance in Internet Finance}

While the information resources are not scarce, the authenticity of the data is more critical. Although through Internet finance, we can grasp that small and micro enterprises leave various transaction data on the trading platform, but they cannot grasp the real capital flow of the blockers, and any data is historical data, which is the past transaction data to judge the future trend. In this case, it is more important to distinguish the authenticity of the data and to control the risk.

Internet finance has advantages in customer data, but the final settlement and basic financial services still need to rely on banks, and banks have absolute advantages in payment settlement services and credibility. The Internet financial platform holds a large number of end-customer data, and has an advantage in understanding customer needs and marketing channel construction. Only when the two are combined can we create a better credit environment for small and micro loans.

Internet finance has technical risks. The service of internet finance is realized by real-time mutual data. Therefore, it is necessary to use electronic information technology to connect the 
bank's financing system with the enterprise's resource management system, and to obtain synergy by sharing data. However, the differences in the existence of each system result in inconsistent data interfaces, and it is difficult for systems to be compatible with each other. In addition, most of the operations are performed online, resulting in most of the information in the transaction process, including transaction information, account information, customer information, etc., which are transmitted on the Internet. Therefore, the confidentiality and security of the electronic information system are particularly important. Moreover, there is a great risk in the form of continuous technological advancement. If the system is subjected to malicious cyber attacks, it will bring huge losses to enterprises and banks.

\section{Suggestions on Internet Finance Helping Small and Micro Enterprises Financing}

For small and micro enterprises, enterprises should strengthen their management and construction, improve their ability to resist risks, and use Internet resources to seek financing channels and solve financial pressures. At the same time, they must also identify the risks brought by uncertainties of the Internet and avoid the combined impact of core business risk. At the same time, Internet finance can only solve the short-term capital needs of small and micro enterprises. For long-term capital needs, we must understand the dynamics of capital markets and grasp the feasible financing channels.

For banks, it is necessary to make full use of electronic information technology and upgrade the platform in time. Ensure the safety and stability of the online platform. Increase the supervision of third-party corporate collateral, and at the same time develop effective risk warning programs to optimize online financing services. At the same time, banks should also integrate resources, explore the financing needs of small and micro enterprises, and innovate financing models. Under reasonable risk conditions, innovation can meet the long-term financing needs of some small and micro enterprises.

On the government side, we must first strengthen supervision over the Internet financial market and improve the regulatory system. For the newly applied for the establishment of Internet financing, the company strictly controls the establishment of the approval process, and supervises and manages its system security technology and enterprise fund utilization. After the establishment, it requires daily management and liquidity to be supervised and managed. It also clarifies the legal status and nature of the Internet environment, the relevant laws and regulations of the system, and regulates Internet finance companies in terms of access conditions, organizational forms, risk control, management methods, punishment methods and management supervision, as well as system and technical security. At the same time, it is strongly supported by policies and funds to provide platform construction and operation for Internet financing for small and micro enterprises, helping them to grow and drive the development of the entire industry.

In short, in the case of good development of policies and environment, the efficient development of Internet finance will become the mainstream of the next period of financial development, and the current need to improve the corresponding rules and regulations and legal provisions, so that Internet finance is healthy within the legal scope. The development, the real benefits bring to the current small and micro enterprises, and at the same time enable the broad masses of society to benefit from it, forming a virtuous circle and healthy development.

\section{References}

[1] Guo Rui. Research on the development of Internet finance leasing business model [D]. Master's degree thesis of Graduate School of Chinese Academy of Social Sciences, 2014

[2] Stiglitz, J.E., and Weiaa, A.M., 1983. Incentive Effects of Terminations: Application to Credit and Labor Markets, American Economic Review, Vol. 73, No. 3; 912-927.

[3] Huang Chao. Research on financing mode of small and micro enterprises under internet finance [D]. Wuhan: Central China Normal University, 2015. 
[4] Fan Xiaohao. Research on the innovation of financing methods for small and micro enterprises in China under the background of internet finance [D] Kunming: Yunnan University, 2015 